\title{
Bacteriocin production by Lactobacillus plantarum ST16Pa in supplemented whey powder formulations
}

\author{
Sabrina S. Sabo, ${ }^{1}$ Attilio Converti, ${ }^{2}$ Simone Ichiwaki, ${ }^{1}$ and Ricardo P. S. Oliveira ${ }^{1 *}$ \\ ${ }^{1}$ Department of Biochemical and Pharmaceutical Technology, Faculty of Pharmaceutical Sciences, University of São Paulo, \\ 05508-000 São Paulo, Brazil \\ ${ }^{2}$ Department of Civil, Chemical and Environmental Engineering, University of Genoa, Pole of Chemical Engineering, via Opera Pia 15, \\ I-16145 Genoa, Italy
}

\section{ABSTRACT}

Whey, the main by-product of the dairy industry, is frequently disposed of in the environment without any treatment due to the high cost of this process. Alternatively, whey can be used as a medium to culture lactic acid bacteria and produce value-added products such as bacteriocins. In this work, we attempted to improve bacteriocin production by Lactobacillus plantarum ST$16 \mathrm{~Pa}$ in a whey powder formulation supplemented with additional sources of carbon, nitrogen, and vitamin $\mathrm{B}_{12}$ at different levels and varying the agitation intensity according to a Plackett-Burman experimental design. Only the addition of tryptone positively influenced the production of this bacteriocin. The results allowed us to identify a supplemented whey formulation, comprising $150 \mathrm{~g} / \mathrm{L}$ of whey total solids plus $10 \mathrm{~g} / \mathrm{L}$ of tryptone and soybean extract, whose fermentation by $L b$. plantarum ST16Pa in shake flasks under agitation at $150 \mathrm{rpm}$ led to a cell-free supernatant with an antimicrobial activity against Listeria innocua 6a CLIST 2865 (inhibition zone of $13.23 \mathrm{~mm}$ ) close to that previously obtained in de Man, Rogosa and Sharpe medium by other authors. These results are significant considering that the same strain cultured in cheese whey did not previously display any antimicrobial activity.

Key words: whey powder, bacteriocin, Lactobacillus plantarum, Plackett-Burman experimental design, antimicrobial activity

\section{INTRODUCTION}

Whey, the major by-product produced by dairy industries, is obtained after clotting and casein removal during cheese manufacturing (Brandelli et al., 2015). For many years, industries sought out cheap disposal methods, including discharge into waterways, sewer

Received April 5, 2018.

Accepted June 19, 2018.

*Corresponding author: rpsolive@usp.br systems, oceans, or fields. These practices have led to many environmental problems due to both the high organic load of whey and its large production (Brandelli et al., 2015; Smithers, 2015). When dumped on land it causes severe pollution in the surrounding environment, affecting the physicochemical characteristics of soil, hence resulting in decreased crop yields. When discharged into water bodies it reduces the dissolved oxygen level and hampers biodegradability, which constitutes a risk for aquatic life (González-Siso, 1996).

Today, the disposal of untreated whey in waterways is unlawful in most countries (Smithers, 2015); therefore, proper management of this by-product is required before its discharge (Yadav et al., 2015). Biological wastewater treatment is the safest method of whey disposal, but it is very expensive (Panesar et al., 2007).

Because whey retains about $55 \%$ of total milk nutrients (Panesar et al., 2007; Prazeres et al., 2012), an economical and advantageous alternative is its use as a substrate to produce value-added compounds by biological means. Among its most abundant nutrients are lactose $(75 \%$ of DM), soluble proteins (12-14\%), and lipids and mineral salts (1-10\%), which are essential for microbial growth, especially for lactic acid bacteria (LAB) (Panesar et al., 2007; Koutinas et al., 2009; Prazeres et al., 2012). Typically, the production of antimicrobial compounds by LAB may be considered somewhat expensive. It was estimated that $30 \%$ of total costs of such a process are related to the culture medium and supplements required to promote the growth of the microorganism producing such molecules (Bali et al., 2016; Sabo et al., 2017). Considering the aforementioned whey nutrients, this by-product can mainly be considered a cheap carbon source that is able to reduce the costs associated with LAB culture medium (Holzapfel, 2002). Besides the economic point of view, the use of whey as an LAB medium component can be thought of as an eco-friendly practice that is able to reduce the effects related to its disposal (Panesar et al., 2007).

Lactic acid bacteria are microorganisms widely used in food industries to develop meat products, vegetables, 
and various dairy products (Cintas et al., 2001). Besides playing an important role in food fermentations and exerting health benefits to consumers, they are known for their ability to produce several biomolecules of industrial interest such as bacteriocins (De Vuyst and Vandamme, 1994). Bacteriocins are defined as bacterially produced, small, heat-stable peptides that are active against other bacteria and to which the producer possesses a specific immunity mechanism (Cotter et al., 2005). Although bacteriocins can be produced by many microorganisms, those produced by LAB have received increased attention over the past decades because they are considered to be "generally recognized as safe" microorganisms (Balciunas et al., 2013).

Among LAB, Lactobacillus is the largest genus, comprising more than 150 species (Siezen et al., 2010). The species Lactobacillus plantarum can adapt to various niches due to its ability to ferment a wide range of carbohydrates (Sabo et al., 2014). Particularly, the strain Lb. plantarum ST16Pa was reported to produce a 6.5$\mathrm{kDa}$ peptide exhibiting antimicrobial activity against many different foodborne pathogenic bacteria, including gram-negative ones (Todorov et al., 2011; Sabo et al., 2015). Moreover, a PCR analysis of $L b$. plantarum ST16Pa DNA evidenced the presence of nisin and enterocin $\mathrm{P}$ genes, but this detection does not guarantee that the strain expresses 1 of these 2 bacteriocins or even a combination of them (Todorov et al., 2014).

Although whey can support the growth of most LAB (Brinques et al., 2010; Panesar et al., 2010; Ünlü et al., 2015), it is lacking in nitrogen and other nutritional components, often requiring their supplementation to satisfactorily sustain bacteriocin production (Briczinski and Roberts, 2002). Moreover, some LAB have an inefficient proteolytic system and are highly dependent on external supplements to synthesize peptides and proteins (Ummadi and Curic-Bawden, 2010; Pleissner and Venus, 2016). In a previous study, Todorov et al. (2011) demonstrated the ability of the strain $L b$. plantarum ST16, when cultivated in de Man, Rogosa and Sharpe (MRS) broth supplemented with different nutrients, to produce a bacteriocin with high antimicrobial activity against several microorganisms. However, when cultured in cheese whey, despite the satisfactory biomass production, this strain did not produce bacteriocin.

Based on this background, the aim of this study was to check the ability of $L b$. plantarum ST16Pa to produce bacteriocin in a medium based on whey, with the aim of making its production profitable from an economic point of view. To find the best production conditions, different whey powder formulations supplemented with additional sources of carbon, nitrogen, and vitamin $\mathrm{B}_{12}$ were tested at different concentrations and different agitation intensities according to a Plackett-Burman (PB) experimental design.

\section{MATERIALS AND METHODS}

\section{Microbial Cultures}

This study was conducted with the probiotic bacteriocin-producing strain $L b$. plantarum ST16Pa previously isolated by Todorov et al. (2011) from papaya. The bacteriocin produced by this strain is referred to here as "bacteriocin ST16Pa." The strain Listeria innocua 6a CLIST 2865 (AL230/07), isolated from a sausage sample and provided by Coleção de Listeria of Fundação Oswaldo Cruz (FioCruz, Rio de Janeiro, Brazil), was used as an indicator microorganism susceptible to bacteriocin antimicrobial activity.

Lactobacillus plantarum ST16Pa and L. innocua 6a CLIST 2865 were cultured in MRS and brain heart infusion (BHI) broths, respectively, both provided by Difco (Detroit, MI), incubated at $30^{\circ} \mathrm{C}$ on an orbital shaker at $100 \mathrm{rpm}$ for $24 \mathrm{~h}$ and then cryopreserved after addition of $20 \%$ (vol/vol) glycerol. Finally, the cryopreserved strains were stored at $-70^{\circ} \mathrm{C}$.

\section{Experimental Design to Improve Bacteriocin ST16Pa Production}

A PB experimental design matrix was used to identify the best medium composition and agitation intensity for bacteriocin production by $L b$. plantarum ST16Pa in whey powder-based medium. Such an experimental design is a 2-level partial factorial design often used to identify significant factors for further investigation (Kennedy and Krouse, 1999). According to these authors, it is a method especially suited to investigate the simultaneous effects of many factors and to cheaply optimize medium composition and culture conditions in fermentation processes through a minimal number of experiments.

For that, 8 variables - whey powder TS content; concentrations of inulin, sucrose, glucose, soybean extract, tryptone, and vitamin $\mathrm{B}_{12}$; and agitation intensity - were screened at 3 levels in 12 triplicate runs, plus 4 triplicate repetitions of the central point. The minimum, central, and maximum levels selected for these variables are listed in Table 1, where columns represent the levels of each independent variable and rows represent the conditions of each run. Lactobacillus plantarum ST16Pa dry cell mass concentration after $48 \mathrm{~h}$ of cultivation and the mean diameter of inhibition zone against the bioindicator strain were used as the response variables. Variables with confidence levels 
$>95 \%$ were considered to have a significant influence on inhibition zones induced by bacteriocin ST16Pa.

The choice to supplement whey powder with glucose (Inlab, São Paulo, Brazil), sucrose (Cromoline Química Fina, São Paulo, Brazil), tryptone (Difco) and vitamin $\mathrm{B}_{12}$ (Inlab) was based on the study of Todorov et al. (2011). Additionally, we tested inulin (Clariant, São Paulo, Brazil) because of its well-known ability to improve the growth of probiotic bacteria. To improve bacteriocin ST16Pa antimicrobial activity, we used soybean extract (Jasmine, Curitiba, Brazil). The addition to whey of this extract as a nitrogen source is expected to be especially advantageous.

\section{Whey Preparation}

Whey powder, kindly provided by BR Foods (São Paulo, Brazil), was used to carry out this study. According to this company, $26 \mathrm{~g}$ of sweet powder whey comprised $20 \mathrm{~g}$ of carbohydrates, $2.9 \mathrm{~g}$ of proteins, 0.6 $\mathrm{g}$ of total fats, $0.5 \mathrm{~g}$ of saturated fats, $0.14 \mathrm{~g}$ of calcium, and $0.22 \mathrm{~g}$ of sodium.

Whey was prepared using different concentrations of TS and diluted in distilled water. According to the methodology of Vignolo et al. (1995) and Guerra and Pastrana (2001), the whey-based solution was acidified to $\mathrm{pH} 4.0$ by the addition of $10 \mathrm{M} \mathrm{HCl}$ and heated at $100^{\circ} \mathrm{C}$ for $30 \mathrm{~min}$ in a thermal bath to denature proteins and remove insoluble compounds. The resulting solution was centrifuged, and the supernatant was adjusted at pH 6.3 using $10 \mathrm{M} \mathrm{NaOH}$ and subsequently supplemented with carbon, nitrogen, and vitamin $\mathrm{B}_{12}$ in accordance with the above-mentioned $\mathrm{PB}$ experimental matrix. Finally, it was pasteurized at $90^{\circ} \mathrm{C}$ for $5 \mathrm{~min}$ in a thermal bath and subsequently cooled in an ice bath for $10 \mathrm{~min}$.

\section{Inoculum Preparation and Culture Conditions}

Lactobacillus plantarum ST16Pa inoculum was prepared by adding $1.0 \mathrm{~mL}$ of culture stock (stored at $-70^{\circ} \mathrm{C}$, for a maximum period of $90 \mathrm{~d}$ ) to $250-\mathrm{mL}$ Erlenmeyer flasks containing $100 \mathrm{~mL}$ of MRS broth and incubated in an orbital shaker at $30^{\circ} \mathrm{C}$ at $100 \mathrm{rpm}$ for $12 \mathrm{~h}$. Then, the fermented medium was diluted with sterile distilled water up to a final concentration of 0.8 to 0.9 optical density units at $650 \mathrm{~nm}$. Ten milliliters of this diluted inoculum $[10 \%(\mathrm{vol} / \mathrm{vol})$ of the final working volume] was centrifuged at $4,470 \times g$ for 15 min at $4^{\circ} \mathrm{C}$. The resulting pellet was washed twice with sterile distilled water and resuspended directly in 10 $\mathrm{mL}$ of the previously treated and supplemented whey solution. The cell washing procedure was adopted to eliminate any MRS residues that could have caused a false-positive bacteriocin production. Finally, the resuspended inoculum was transferred into $250-\mathrm{mL}$ Er-

Table 1. Plackett-Burman experimental design matrix used to identify the best medium composition and agitation intensity for the production of bacteriocin ST16Pa by Lactobacillus plantarum ST16Pa in supplemented whey powder formulations ${ }^{1}$

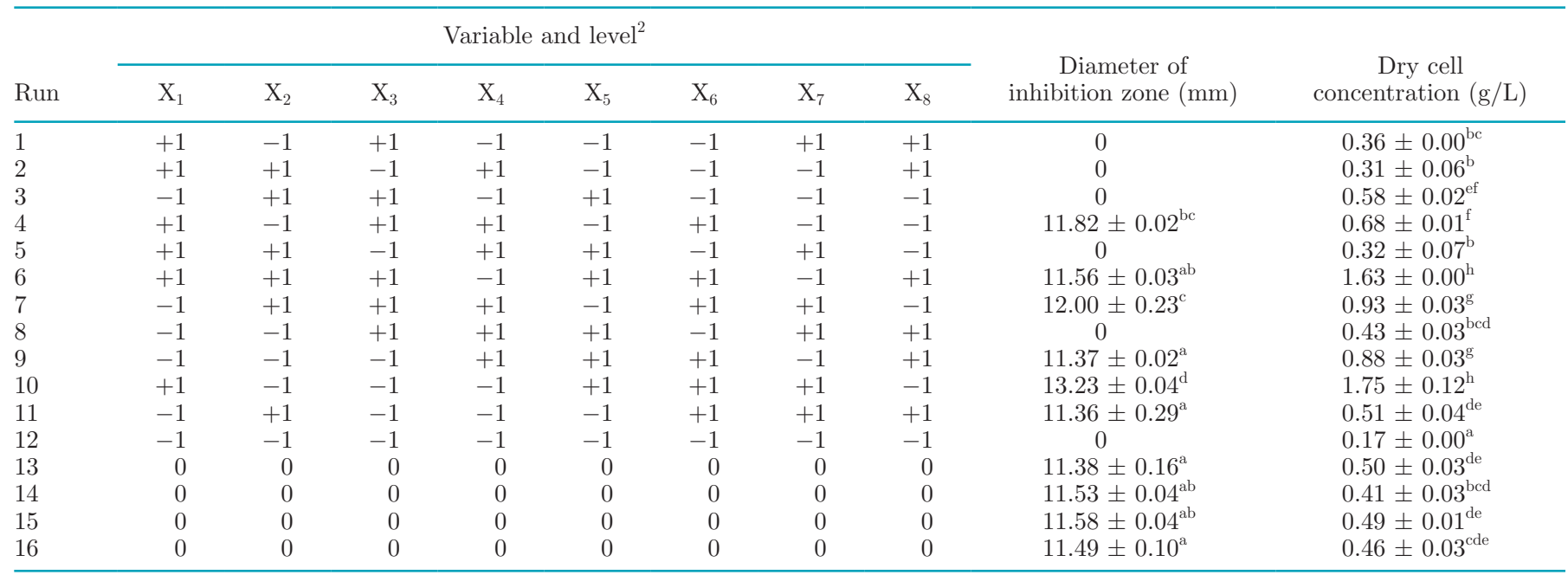

\footnotetext{
${ }^{\mathrm{a}-\mathrm{h}}$ Different superscripts within in the same column mean that values significantly differ $(P<0.05)$.

${ }^{1}$ The results are expressed as Lb. plantarum ST16Pa dry cell concentration after $48 \mathrm{~h}$ of cultivation $(\mathrm{g} / \mathrm{L})$ and main diameter of inhibition zone against Listeria innocua 6a CLIST $2865(\mathrm{~mm})$ as the bioindicator strain.

${ }^{2}$ The coded levels $+1,0$, and -1 refer to the highest, central, and lowest levels of variables. $\mathrm{X}_{1}=$ whey powder TS content: 150,100 , and $50 \mathrm{~g} / \mathrm{L}$; $\mathrm{X}_{2}=$ inulin concentration: 20,10 , and $0 \mathrm{~g} / \mathrm{L} ; \mathrm{X}_{3}=$ sucrose concentration: 30,15 , and $0 \mathrm{~g} / \mathrm{L} ; \mathrm{X}_{4}=$ glucose concentration: 30,15 , and $0 \mathrm{~g} / \mathrm{L} ; \mathrm{X}_{5}$ $=$ soybean extract concentration: 10,5 , and $0 \mathrm{~g} / \mathrm{L} ; \mathrm{X}_{6}=$ tryptone concentration: 10,5 , and $0 \mathrm{~g} / \mathrm{L} ; \mathrm{X}_{7}=$ vitamin $\mathrm{B}_{12}$ concentration: $1.6,0.8$, and $0 \mathrm{mg} / \mathrm{L} ; \mathrm{X}_{8}=$ agitation intensity: 150,100 , and $50 \mathrm{rpm}$. Mean values $(\mathrm{n}=3) \pm \mathrm{SD}$.
} 
lenmeyer flasks containing $90 \mathrm{~mL}$ of previously treated and supplemented whey powder.

All the cultures were performed in triplicate, incubating the flasks at $30^{\circ} \mathrm{C}$ for $48 \mathrm{~h}$ in an orbital shaker at the selected agitation intensity. Samples were collected after this period to determine $L b$. plantarum dry cell mass concentration and measure the inhibition zones induced by bacteriocin ST16.

\section{Scaling Up in Bioreactor and Fermentation Parameters}

Based on the results of runs carried out in flasks according to the PB experimental design, the supplemented whey powder formulation that ensured the best performance was scaled up to a 2-L stirred tank bioreactor (Biostat B plus Sartorius, Göttingen, Germany). For this purpose, $0.9 \mathrm{~L}$ of medium containing such supplemented whey powder was transferred to the tank, and subsequently $100 \mathrm{~mL}$ of inoculum suspension was added. Cultures were conducted in triplicate under conditions as much as possible coincident with those performed in shake flasks.

Samples were collected every $2 \mathrm{~h}$ during $12 \mathrm{~h}$ and then after 24 and $48 \mathrm{~h}$ of fermentation and were analyzed for $L b$. plantarum ST16Pa dry cell concentration, mean diameter of inhibition zone induced by bacteriocin ST16Pa, and lactate and lactose concentrations. These experimental data were then used to calculate the main fermentation parameters such as the yields of biomass and lactate on consumed lactose ( $Y \frac{\text { biomass }}{\text { lactose }}$ and $Y \frac{\text { lactate }}{\text { lactose }}$, respectively), the global biomass and lactate volumetric productivities ( $Q_{\text {biomass }}$ and $Q_{\text {lactate }}$, respectively), the maximum specific growth rate $\left(\mu_{\max }\right)$, and the generation time $\left(T_{\mathrm{g}}\right)$ according to the equations

$$
\begin{gathered}
Y \frac{\text { biomass }}{\text { lactose }}=\frac{\left(X_{f}-X_{i}\right)}{\left(S_{f}-S_{i}\right)}, \\
Y \frac{\text { lactate }}{\text { lactose }}=\frac{\left(P_{L A C f}-P_{L A C i}\right)}{\left(S_{f}-S_{i}\right)}, \\
Q_{\text {biomass }}=\frac{\left(X_{f}-X_{i}\right)}{T_{f}}, \\
Q_{\text {lactate }}=\frac{\left(P_{L A C f}-P_{L A C i}\right)}{T_{f}},
\end{gathered}
$$

$$
\mu_{\max }=\frac{1}{\left(T_{f}-T_{i}\right)} \ln \frac{X_{f}}{X_{i}}
$$

and

$$
T_{\mathrm{g}}=\frac{\ln 2}{\mu_{\max }},
$$

where $X_{f}$ and $X_{i}$ are the final and initial biomass concentrations, $S_{f}$ and $S_{i}$ are the final and initial lactose concentrations, $P_{L A C f}$ and $P_{L A C i}$ are the final and initial lactate concentrations, and $T_{f}$ and $T_{i}$ are the final and initial times. To evaluate the reproducibility of run in a bioreactor, these parameters were compared with those obtained in runs carried out in shake flasks under comparable conditions using the same supplemented whey powder formulation.

\section{Determination of Lactose and Lactate Concentrations}

To determine the concentrations of lactose and lactate, samples were aseptically collected and centrifuged at $3,421 \times g$ for $15 \mathrm{~min}$. The supernatant was filtered through membranes with $0.22-\mu \mathrm{m}$ pore diameter (Millipore, Bedford, MA) and analyzed using an HPLC device (Ultimate 3000, Dionex, Sunnyvale, CA) equipped with a refractive index detector (Shodex RI-210, Kawasaki, Kanagawa, Japan) and an HPX-87H column (Bio-Rad, Hercules, CA). Analyses were carried out at $50^{\circ} \mathrm{C}$ using $5.0 \mathrm{mM} \mathrm{H} \mathrm{H}_{2} \mathrm{SO}_{4}$ as mobile phase at a flow rate of $0.6 \mathrm{~mL} / \mathrm{min}$. High-purity lactose and lactate (Sigma-Aldrich, St. Louis, MO) were used at concentrations from 0.1 to $10.0 \mathrm{~g} / \mathrm{L}$ as standard solutions to prepare the corresponding calibration curves.

\section{Cell Growth}

The growth of Lb. plantarum ST16Pa was monitored by counting colony-forming units per milliliter using the serial dilution technique, in which $0.5 \mathrm{~mL}$ of the sample was serially 10 -fold diluted in $4.5 \mathrm{~mL}$ of $0.85 \%$ (wt/vol) sterile saline. Subsequently, $100 \mu \mathrm{L}$ of each dilution was transferred to Petri dishes $(90 \times 15 \mathrm{~mm})$ containing MRS broth gelled with 1.5\% (wt/vol) agar. With the aid of a sterile Drigalski handle, the diluted samples were spread over the surface of the medium, and the plates were incubated for $48 \mathrm{~h}$. Only plates containing 30 to 300 colonies were considered. Each count determination was performed in triplicate, and the results were expressed as mean values.

To convert colony-forming units per milliliter to cell dry concentration (g/L), Lb. plantarum ST16Pa was 
cultivated in MRS broth and incubated in an orbital shaker at $30^{\circ} \mathrm{C}$ and $100 \mathrm{rpm}$. To this purpose, a calibration curve described by the equation $y=8.10^{7} x-1.10^{7}$ $\left(\mathrm{R}^{2}=0.98\right)$ was obtained by plotting the colony-forming units per milliliter values versus the corresponding dry cell mass concentrations obtained by filtration of cell-containing MRS broth through membranes with a $0.22-\mu \mathrm{m}$ pore diameter (Millipore).

\section{Bacteriocin Antimicrobial Activity Assay}

Bacteriocin ST16Pa antimicrobial activity was determined in triplicate, according to the spot-on-the-lawn method (van Reenen et al., 1998), on cell-free supernatants (CFS) of broth samples previously centrifuged at $25,750 \times g$ at $4^{\circ} \mathrm{C}$ for $10 \mathrm{~min}$, and $\mathrm{pH}$ was adjusted to 6.0 with $1.0 \mathrm{M} \mathrm{NaOH}$. Petri dishes containing $10 \mathrm{~mL}$ of melted BHI soft agar [supplemented with $0.75 \%$ agar (wt/vol)] were previously inoculated with $1.0 \mathrm{~mL}$ of a 100-fold-diluted overnight-aged suspension of the bioindicator microorganism (approximately $10^{8} \mathrm{cfu} / \mathrm{mL}$ ). It is noteworthy that such a low agar concentration was selected based on previous observation that high agar concentrations, responsible for an increased matrix density, affected the diameter of the inhibition zone, slowing down the diffusion of the bacteriocin molecules (Blom et al., 1997).

After agar gelation, $20 \mu \mathrm{L}$ of CFS was dropped onto the BHI soft agar surface and incubated at $30^{\circ} \mathrm{C}$ for $24 \mathrm{~h}$. Next, the diameters of the bacteriocin-induced inhibition zones were measured by means of a digital caliper (model 684132; Lee Tools, São Paulo, Brazil) in 4 different directions and expressed as mean values in millimeters.

The antimicrobial activity of CFS from whey powder formulations that ensured the largest bacteriocin ST16Pa inhibition zones was also quantified by serial 2-fold dilutions in $25 \mathrm{mM}$ phosphate buffer at pH 6.5. The concentration of bacteriocin produced by $L b$. plantarum ST16Pa was expressed in arbitrary units (AU) per milliliter by the equation

$$
\mathrm{AU} / \mathrm{mL}=D^{\mathrm{n}} \times 1,000 / P,
$$

where $D=$ dilution factor, $n=$ first dilution showing no inhibition zone, and $P=$ volume $(\mu \mathrm{L})$ of supernatant spread onto the agar surface.

\section{Inhibition Zones Stability}

To check whether the bacteriocin produced in the supplemented whey powder formulation that ensured the best performance had the same protein nature and stability as that described by Todorov et al. (2011) cul- turing Lb. plantarum ST16Pa in MRS broth, the effects of digestive enzymes, chemicals, and temperature on the inhibition zones were also investigated. To this purpose, the $\mathrm{pH}$ of CFS from bioreactor broths was adjusted to 6.0 with $1.0 \mathrm{M} \mathrm{NaOH}$, and $1.0-\mathrm{mL}$ aliquots were incubated at $30^{\circ} \mathrm{C}$ for $2 \mathrm{~h}$ in the presence of $1.0,5.0$, or $30 \mathrm{mg} / \mathrm{mL}$ of chymotrypsin, trypsin, protease XIV, and $\alpha$-amylase (all purchased from Sigma-Aldrich). Additional 1.0-mL aliquots of CFS were individually treated with 1.0\% (wt/vol) SDS (Inlab), urea (Synth, São Paulo, Brazil), EDTA (Inlab), or $\mathrm{NaCl}$ (Synth) or with $1.0 \%$ (vol/vol) Triton X-100 (Inlab), Tween 20 (Inlab), or Tween 80 (Inlab) and then incubated at $30^{\circ} \mathrm{C}$ for 1 h. The effect of temperature on the inhibition zones was investigated by heating CFS in a thermoregulated bath at $40,60,80$, and $100^{\circ} \mathrm{C}$ for $1 \mathrm{~h}$ and at $121^{\circ} \mathrm{C}$ for $20 \mathrm{~min}$. All the samples were tested for antimicrobial activity against the bioindicator strain $L$. innocua $6 \mathrm{a}$ CLIST 2865 according to the spot-on-the-lawn method described above. Untreated CFS served as controls.

\section{Effect of Bacteriocin ST16Pa on the Growth of the Bioindicator Microorganism}

A 4.5-mL aliquot of CFS from the bioreactor broth was added to 100-mL Erlenmeyer flasks containing 30.5 $\mathrm{mL}$ of BHI broth previously inoculated with $0.35 \mathrm{~mL}$ of an overnight-aged L. innocua 6a CLIST 2865 suspension. The control assay was carried out under the same conditions described above but without CFS. Then, the flasks were incubated at $37^{\circ} \mathrm{C}$ in an orbital shaker at $100 \mathrm{rpm}$ for $6 \mathrm{~h}$. Optical density measurements at 600 nm were recorded every hour.

\section{Bacteriocin-Induced Reduction of Bioindicator Microorganism Viability}

The pellet resulting from centrifugation at $4,470 \times$ $g$ at $4^{\circ} \mathrm{C}$ for $15 \mathrm{~min}$ of an overnight-aged culture of $L$. innocua 6a CLIST 2865 was washed twice with $0.85 \%$ (wt/vol) sterile saline solution and resuspended in 10 $\mathrm{mL}$ of the same solution. An equal volume of CFS from the bioreactor was mixed with the resuspended pellet, and the number of viable cells was counted, either before or after incubation at $37^{\circ} \mathrm{C}$ for $1 \mathrm{~h}$, by plating these solutions onto BHI broth supplemented with $1 \%$ (wt/ vol) agar and incubating the plates at $37^{\circ} \mathrm{C}$ for $48 \mathrm{~h}$. Cell suspensions of the bioindicator strain without CFS served as controls.

\section{Purification of Bacteriocin ST16Pa}

The $\mathrm{pH}$ of a $100-\mathrm{mL}$ aliquot of CFS from the bioreactor was adjusted to 6.0 with $1.0 \mathrm{M} \mathrm{NaOH}$ and 
was subsequently used for further assays. Bacteriocin ST16Pa was precipitated by adding ammonium sulfate to CFS in order to obtain $30 \%$ (wt/vol) saturation and then stirred at $4^{\circ} \mathrm{C}$ for $2 \mathrm{~h}$. The pellet resulting from centrifugation at $4,470 \times g$ at $4^{\circ} \mathrm{C}$ for 30 min was resuspended in $10 \mathrm{~mL}$ of $25 \mathrm{mM}$ ammonium acetate buffer ( $\mathrm{pH}$ 6.5) and loaded on a previously activated $\mathrm{C}_{18}$ solid phase extraction (SPE) cartridge (model Oasis HLB; Waters, Millipore), which was eluted with isopropanol solutions in the same buffer with gradually increasing concentration $[20,40,60$, and $80 \%$ (vol/vol)]. To control and validate the proposed protocol, $L b$. plantarum ST16Pa was cultured in MRS broth at $30^{\circ} \mathrm{C}$ for $24 \mathrm{~h}$, and the resulting CFS was treated as previously described.

The antimicrobial activity was tested against $L$. innосиа 6 a CLIST 2865 by the spot-on-the-lawn method as previously described. The protein concentration after each step was determined using the BCA protein assay reagent (Sigma-Aldrich) as specified by the manufacturer and a calibration curve $(y=0.0011 x$ $\left.+0.00245 ; \mathrm{R}^{2}=0.99\right)$. It was possible to determine the total antimicrobial activity (AU), specific activity $(\mathrm{AU} / \mathrm{mL})$, yield $(\%)$, and purification fold.

\section{Statistical Analysis}

The results of cultures performed according to the PB experimental design matrix were analyzed using Minitab 17 Statistical Software (Minitab Inc., State College, PA) and statistically worked out by ANOVA.

\section{RESULTS AND DISCUSSION}

\section{Bacteriocin ST16Pa Production in Shake Flasks}

The individual effects of whey powder TS content, agitation intensity, and concentrations of tryptone, sucrose, soybean extract, glucose, vitamin $\mathrm{B}_{12}$, and inulin on $L b$. plantarum ST16Pa cultures were investigated in shake flasks at $30^{\circ} \mathrm{C}$ according to a $\mathrm{PB}$ experimental design. The results of these runs collected after $48 \mathrm{~h}$ are listed in Table 1 in terms either of mean diameters of inhibition zones against L. innocua 6a CLIST 2865 as a bioindicator strain or of $L b$. plantarum ST16Pa dry cell concentration.

An additional control run was performed out of the $\mathrm{PB}$ experimental matrix by culturing $L b$. plantarum ST16Pa on nonsupplemented whey powder under the same conditions as those of the central point of the experimental design $(100 \mathrm{~g} / \mathrm{L}$ of total whey solids content, $\left.30^{\circ} \mathrm{C}, 100 \mathrm{rpm}\right)$. Even though the strain was able to slightly grow under these conditions $(0.22 \mathrm{~g} / \mathrm{L})$, the broth CFS did not display any antimicrobial activity, thus confirming the observations of Todorov et al. (2011) on the same strain grown on cheese whey (20 or $100 \mathrm{~g} / \mathrm{L}$ of TS) as a fermentation substrate.

On the other hand, 10 of the 16 whey powder formulations tested according to the $\mathrm{PB}$ experimental matrix allowed for considerably higher growth of $L b$. plantarum ST16Pa and satisfactory bacteriocin ST16Pa antimicrobial activity (runs 4, 6, 7, 9, 10, 11, and 13-16). Taking all the runs as a whole, both biomass concentration and mean diameter of inhibition zones varied markedly (from 0.17 to $1.75 \mathrm{~g} / \mathrm{L}$ and from 0.00 to 13.23 $\mathrm{mm}$, respectively), hence highlighting the importance of optimizing the medium to enhance bacteriocin production.

The Pareto chart illustrated in Figure 1 shows that only the addition of tryptone as a medium supplement led to a statistically significant increase in the mean diameter of the inhibition zone induced by bacteriocin ST16Pa (at a 95\% confidence level). In fact, irrespective of tryptone concentration, all the CFS of culture broths in which this compound was used as an ingredient displayed inhibition zones up to $11.00 \mathrm{~mm}$, and when tryptone was not used as a supplement no antimicrobial activity was observed (Table 1).

Todorov et al. (2011) also reported an increase in bacteriocin ST16Pa activity from 25,600 to 51,200 $\mathrm{AU} / \mathrm{mL}$ when $L b$. plantarum ST16Pa was cultured in MRS broth supplemented with $20 \mathrm{~g} / \mathrm{L}$ of tryptone. Our results also agree with those reported for sakacin $\mathrm{P}$ production by Lactobacillus sakei CCUG 42687 (Aasen et al., 2000), for bacteriocin ST341LD produced by $L b$. plantarum ST341LD (Todorov and Dicks, 2005), and recently for bacteriocins produced by Lactococcus lactis 19.3 and Enterococcus durans 41.2 (Zamfir et al., 2016). This occurrence may be ascribed to the fact that tryptone serves as a source of various AA that are essential for the biosynthesis of bacteriocin or even act as its inducers (Cabo et al., 2001).

After analyzing the Pareto chart, we decided to carry out additional runs at $30^{\circ} \mathrm{C}$ and $100 \mathrm{rpm}$ for $48 \mathrm{~h}$ in 250-mL Erlenmeyer flasks containing $100 \mathrm{~mL}$ of broth based on a whey powder formulation comprising 150 $\mathrm{g} / \mathrm{L}$ of TS supplemented with tryptone as the sole ingredient at different concentrations $(3,10$, or $17 \mathrm{~g} / \mathrm{L})$. The CFS from these samples did not show any inhibition zone, likely due to some drawback inherent to the PB experimental design - that is, it does not allow knowing whether the effect of one factor depends on another factor or assumes that the most important effects are much larger than 2-factor interactions (Montgomery et al., 1997). Moreover, according to Myer and Montgomery (2002), the main effects can be confused with 
second-order interactions, and second-order interactions can be confused with each other. Based on these considerations, we suspect that the improved inhibition zones obtained in this work in the presence of tryptone may have been due also to another independent variable, which could not be identified because of the features of the selected experimental design. Therefore, the subsequent study in the bioreactor was performed using the whey powder formulation that ensured the largest bacteriocin ST16Pa inhibition zone $(13.23 \mathrm{~mm})$ and the highest biomass concentration $(1.75 \mathrm{~g} / \mathrm{L}$; run 10), although bacteriocin ST16Pa production seemed not to be strictly associated with the microbial growth (Figure 2).

According to Kim et al. (1997) and Bogovič-Matijašić and Rogelj (1998), bacteriocin production is strongly dependent on $\mathrm{pH}$, nutrient sources, and incubation temperature, but the activity levels are not always related to the cell mass concentration or growth rate of the producing strain. In addition, an increase in bacteriocin production can occasionally be obtained under suboptimal conditions (De Vuyst et al., 1996).

\section{Culture in Bioreactor and Kinetic Parameters}

The conditions and whey powder formulation composition of run 10, which ensured the best performance in shake flasks (Table 1), were adopted to carry out a cultivation in a 2.0-L bioreactor. As can be seen in Table 2 , there were no considerable differences between the values of biomass concentration, bacteriocin ST16Pa activity expressed in arbitrary units per milliliter, lac- tate concentration, and main fermentation parameters in shake flasks and bioreactor.

\section{Effect of Proteolytic Enzymes, Chemicals, and Temperature on Bacteriocin ST16Pa Antimicrobial Activity}

The CFS from bioreactor-fermented broth (supplemented whey powder formulation that ensured the best performance; run 10) was used to evaluate the effects of proteolytic enzymes, chemicals, and temperature on bacteriocin antimicrobial activity. The results of these tests, expressed in terms of inhibition zone diameter (Table 3), should be evaluated by comparing them with the CFS without any treatment $(13.23 \mathrm{~mm})$.

The CFS treated with $1.0,5.0$, and $30.0 \mathrm{mg} / \mathrm{mL}$ of chymotrypsin, trypsin, and protease XIV resulted in complete inactivation of bacteriocin ST16Pa antimicrobial activity against the bioindicator strain. When treated with $1.0 \mathrm{mg} / \mathrm{mL}$ of $\alpha$-amylase, the inhibition zone had a diameter $(13.00 \mathrm{~mm})$ only $2 \%$ shorter than that of the CFS without any treatment, whereas it was completely suppressed when higher concentrations of the same enzyme $(5.0$ and $30.0 \mathrm{mg} / \mathrm{L})$ were used. Figure 3 shows that, when the CFS was treated with 30.0 $\mathrm{mg} / \mathrm{mL}$ of all the enzymes, the inhibition zones, usually circular, became deformed.

Despite the loss of antimicrobial activity at high $\alpha$-amylase concentration, our results corroborate with those of Todorov et al. (2011), who reported no effect of $1.0 \mathrm{mg} / \mathrm{mL}$ of this enzyme on bacteriocin ST16 stability. Taking into account that $\alpha$-amylase is produced

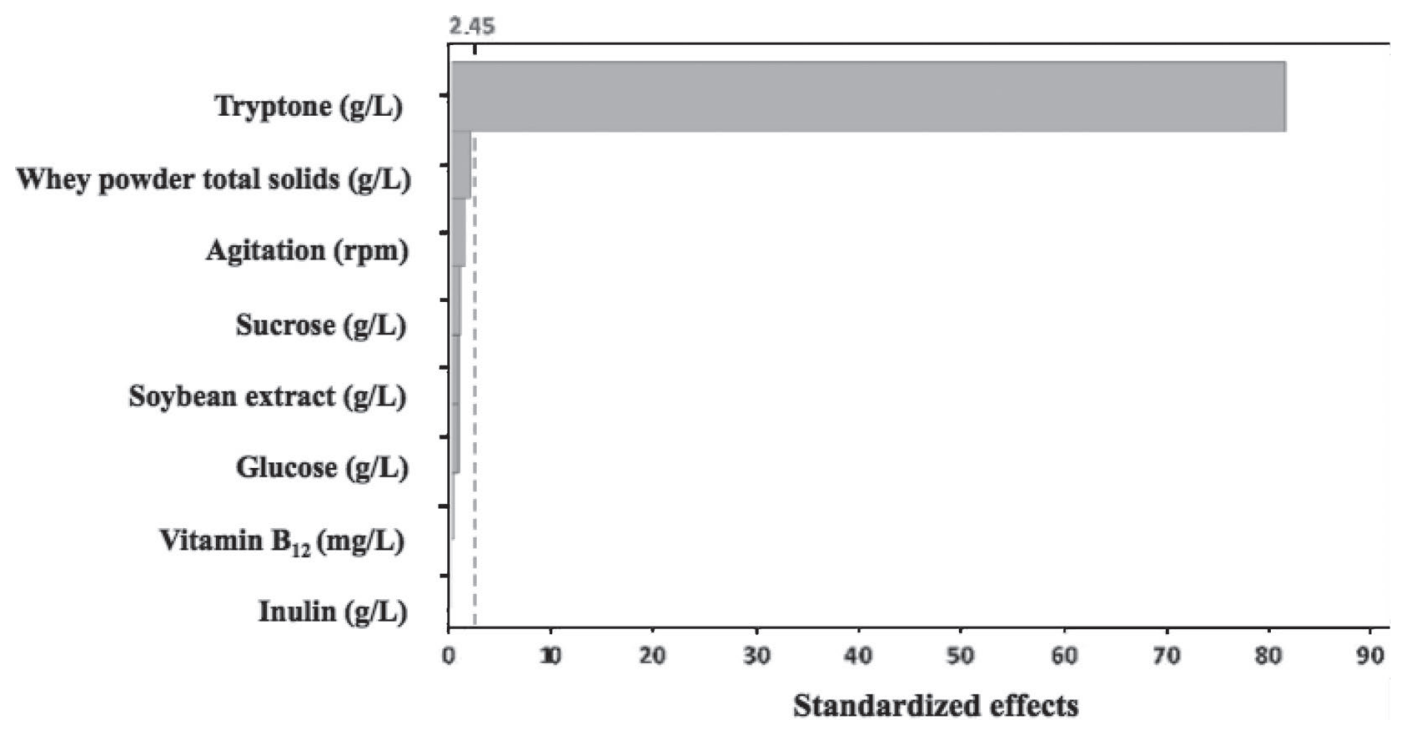

Figure 1. Pareto chart showing the individual effects, according to the Plackett-Burman experimental design, of whey powder TS content, agitation intensity, and concentrations of tryptone, sucrose, soybean extract, glucose, vitamin $\mathrm{B}_{12}$, and inulin on bacteriocin ST16Pa antimicrobial activity against Listeria innocua 6a CLIST 2865. 
Table 2. Comparison of the results of Lactobacillus plantarum ST16Pa cultures carried out in shake flasks and bioreactor on the whey powder formulation of run 10 according to the Plackett-Burman experimental design (Table 1)

\begin{tabular}{lcc}
\hline Item $^{1}$ & Shake flask & Bioreactor \\
\hline Biomass concentration $(\mathrm{g} / \mathrm{L})$ & 1.50 & 1.56 \\
Bacteriocin ST16Pa activity $(\mathrm{AU} / \mathrm{mL})$ & 1,600 & 1,600 \\
Lactate concentration $\left.(\mathrm{g} / \mathrm{L})^{-1}\right)$ & 8.85 & 8.61 \\
$\mu_{\max }\left(\mathrm{h}^{-1}\right)$ & 0.48 & 0.48 \\
$T_{\mathrm{g}}(\mathrm{h})$ & 1.44 & 1.44 \\
$Q_{\text {lactate }}(\mathrm{g} / \mathrm{L}$ per hour $)$ & 0.18 & 0.18 \\
$Q_{\text {biomass }}(\mathrm{g} / \mathrm{L}$ per hour & 0.03 & 0.03 \\
$Y_{\text {biomass/lactose }}(\mathrm{g} / \mathrm{g})$ & 0.08 & 0.07 \\
$Y_{\text {lactate } / \text { lactose }}(\mathrm{g} / \mathrm{g})$ & 0.46 & 0.39 \\
\hline
\end{tabular}

${ }^{1} \mu_{\max }=$ maximum specific growth rate; $T_{\mathrm{g}}=$ generation time; $Y_{\text {biomass/lactose }}=$ biomass yield on consumed lactose $; Y_{\text {lactate/lactose }}=$ lactate yield on consumed lactose; $Q_{\text {biomass }}=$ overall biomass volumetric productivity; $Q_{\text {lactate }}$ $=$ overall lactate volumetric productivity. Fermentation parameters were estimated after $48 \mathrm{~h}$ of cultivation.

by salivary glands and its main function is to initiate starch digestion (Cardoso et al., 2017), we also agree with the suggestion of Todorov et al. (2011) that bacteriocin ST16Pa does not belong to the controversial group IV of bacteriocins, which contain carbohydrates or lipids in the active molecule structure. Keppler et al. (1994) and Seo et al. (2014) also related partial or total loss of bacteriocins antimicrobial activity when the CFS was treated with $\alpha$-amylase, likely due to the hydrolysis of a carbohydrate moiety, which is essential for their activity. However, this effect was observed with $\alpha$-amylase concentrations of 1.0 and $0.1 \mathrm{mg} / \mathrm{mL}$, respectively, which are much lower than that used in the present work $(5 \mathrm{mg} / \mathrm{mL})$, thus suggesting a quite different behavior.
Regarding the effect of chemicals, Tween 20, Tween 80, $\mathrm{NaCl}$, urea, and EDTA did not significantly influence the inhibition zones. Similar stability was observed for the same bacteriocin produced in MRS broth (Todorov et al., 2011). On the other hand, SDS led to a $20 \%$ increase and Triton X-100 to a $23 \%$ reduction of the inhibition zone diameter. A similar negative effect of Triton X-100 on bacteriocin stability was reported by Todorov and Dicks (2005), a possible cause of which may have been the interaction of this uncharged surfactant with the bacteriocin that may have changed its tertiary structure to a less active form. On the other hand, the positive effect of SDS may be simply ascribed to the slight antimicrobial activity of this detergent that, when diluted in sterile water up to $1 \%$ (wt/vol)

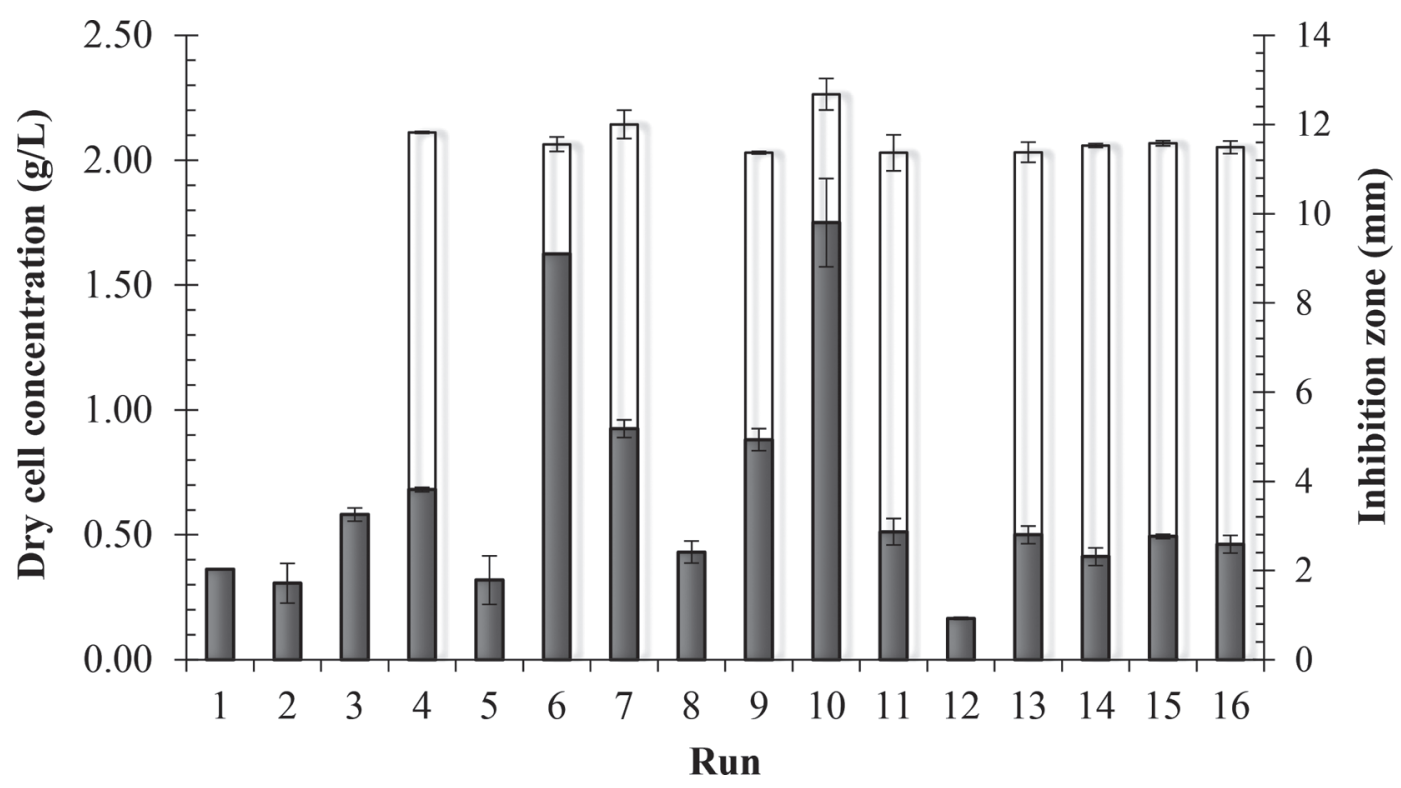

Figure 2. Lactobacillus plantarum ST16Pa dry cell concentration (gray bars) and mean diameter of inhibition zone (white bars). Run numbering is the same as that of the Plackett-Burman experimental design in Table 1. 
Table 3. Characterization of bacteriocin ST16Pa from bioreactor cell-free supernatants (obtained from the supplemented whey powder formulation corresponding to run 10) in terms of effects of proteolytic enzymes, chemicals, and temperature on the diameter of inhibition zones against Listeria innocua 6a CLIST $2865^{1}$

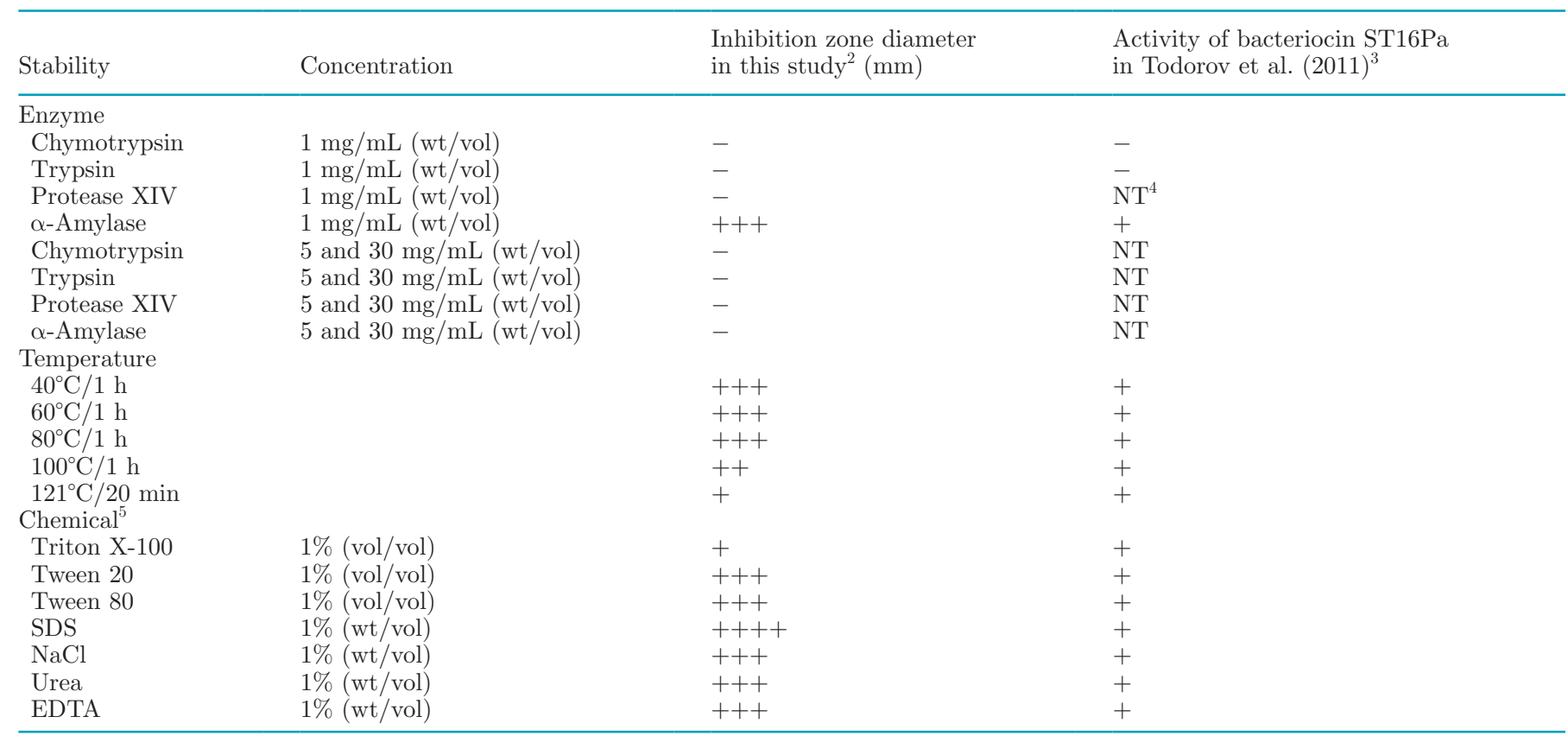

${ }^{1}$ The effect was compared with that reported by Todorov et al. (2011), who tested bacteriocin ST16Pa activity against Enterococcus faecalis ATCC 19443.

${ }^{2}$ Inhibition zone diameter:,$++++>14.0 \mathrm{~mm} ;+++, 12.5-13.9 \mathrm{~mm} ;++, 11.0-12.4 \mathrm{~mm} ;+, 10.0-10.9 \mathrm{~mm}$; -, no inhibition zone.

${ }^{3}$ These authors did not report the inhibition zone diameter but rather only the presence $(+)$ or not $(-)$ of inhibition zones.

${ }^{4}$ Not tested.

${ }^{5}$ Triton X-100, Tween 20, Tween 80, SDS, and EDTA were from Inlab (São Paulo, Brazil), the NaCl and urea were from Synth (São Paulo, Brazil).

and used as a control, induced a 5.0-mm inhibition zone against $L$. innocua 6a CLIST 2865, resulting in a synergistic effect of the bacteriocin ST16Pa antimicrobial activity. The same occurrence was noticed by Azhar et al. (2017), but in this case the authors reported that SDS caused disaggregation of large molecules present

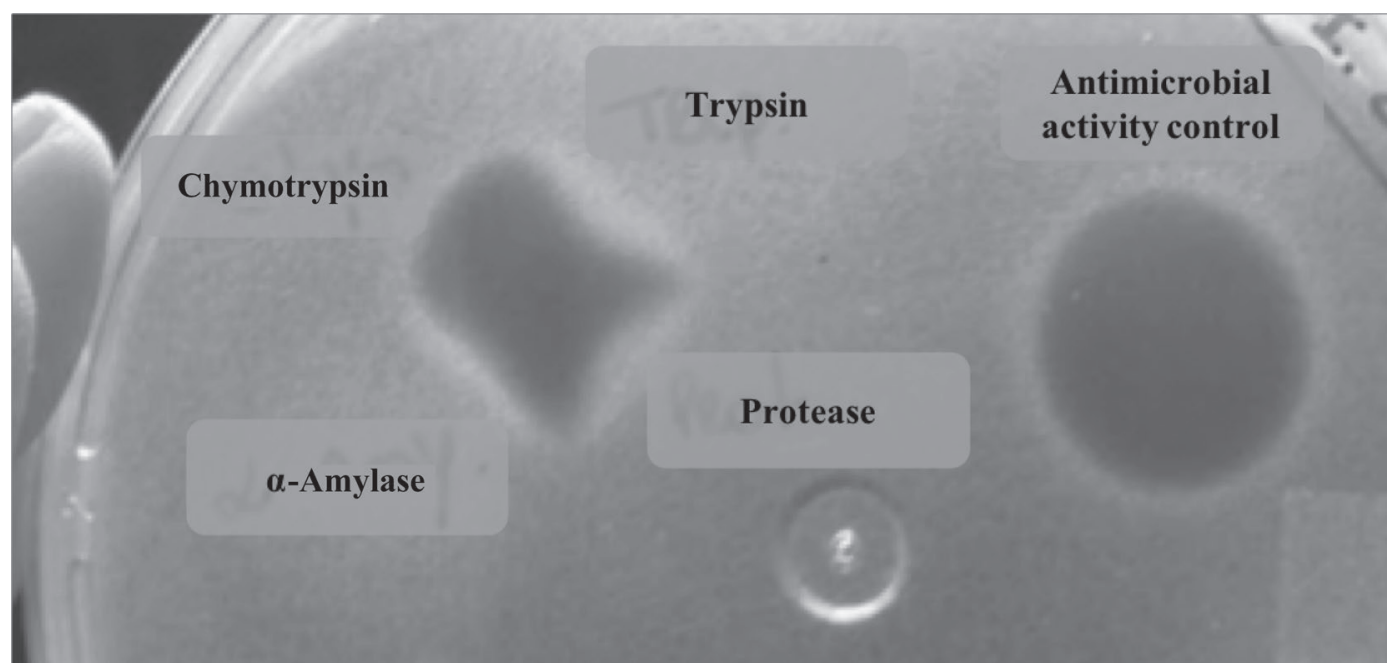

Figure 3. Effect of $30 \mathrm{mg} / \mathrm{L}$ of proteolytic enzymes on inhibition zones induced by cell-free supernatant from Lactobacillus plantarum ST16Pa culture in bioreactor. 
in the tested cell-free supernatant, resulting in a significant increase in antimicrobial effects.

The inhibition zones induced by bacteriocin ST16Pa also remained stable after $1 \mathrm{~h}$ of treatment at 40,60, and $80^{\circ} \mathrm{C}$ and suffered only a slight shortening upon heat treatment at $100^{\circ} \mathrm{C}$ for $1 \mathrm{~h}$ (by $15 \%$ ) or at $121^{\circ} \mathrm{C}$ for 20 min (by 19\%). Such heat stability, which is consistent with the results reported for several bacteriocins produced by different strains of $L b$. plantarum (Lee and Paik, 2001; Wen et al., 2016), would be a very useful feature for a food preservative, considering that many food-processing procedures involve a heating step (Xie et al., 2011).

\section{Antimicrobial Mode of Action of Bacteriocin ST16Pa Against the Bioindicator Strain}

The CFS from bioreactor-fermented broth dramatically inhibited the L. innocua 6a CLIST 2865 growth, exhibiting an optical density value at $650 \mathrm{~nm}$ after 6 $\mathrm{h}$ of cultivation (0.39) that was much lower than the control (1.72; Figure 4). When the overnight-aged cells of the bioindicator strain were put in contact with the same CFS for $1 \mathrm{~h}$, the viable cell counting decreased from 9.13 to $8.40 \log \mathrm{cfu} / \mathrm{mL}$, confirming the bactericidal mode of action with cell lysis and enzyme leakage reported by Todorov et al. (2011). Taking into account that the US Food and Drug Administration and other food safety organizations recommend a zero-tolerance level (Archer, 2018) or an upper limit of $100 \mathrm{cfu} / 25 \mathrm{~g}$ for Listeria in ready-to-eat foods (Swaminathan and Gerner-Smidt, 2007; Voysey and Betts, 2017) and that such a high $L$. innocua contamination level is very unlikely to occur in foods, the almost $1 \log$ reduction observed here would be of great significance from a public health standpoint.

\section{Purification of Bacteriocin ST16 Obtained in MRS Broth and in Supplemented Whey Powder Formulation}

The CFS of the supplemented whey powder fermented by $L b$. plantarum ST16Pa in bioreactor as well as that obtained in MRS broth, taken as a control, were submitted to a purification protocol with the aim to increase bacteriocin ST16 antimicrobial activity. To this purpose, both CFS were first concentrated by adding 30\% (wt/vol) ammonium sulfate and then loaded on a previously activated $\mathrm{C}_{18} \mathrm{SPE}$ Oasis HLB cartridge using $40 \%$ isopropanol in $25 \mathrm{~m} M$ ammonium acetate buffer $(\mathrm{pH} 6.5)$ as an eluent. Table 4 summarizes the results of bacteriocin $\mathrm{ST} 16 \mathrm{~Pa}$ antimicrobial activity, total antimicrobial activity, specific activity, yield, and purification fold either in both CFS or after each of these purification steps.

The proposed purification protocol was effective in the purification of bacteriocin ST16Pa produced in MRS broth. After the final SPE step, despite the

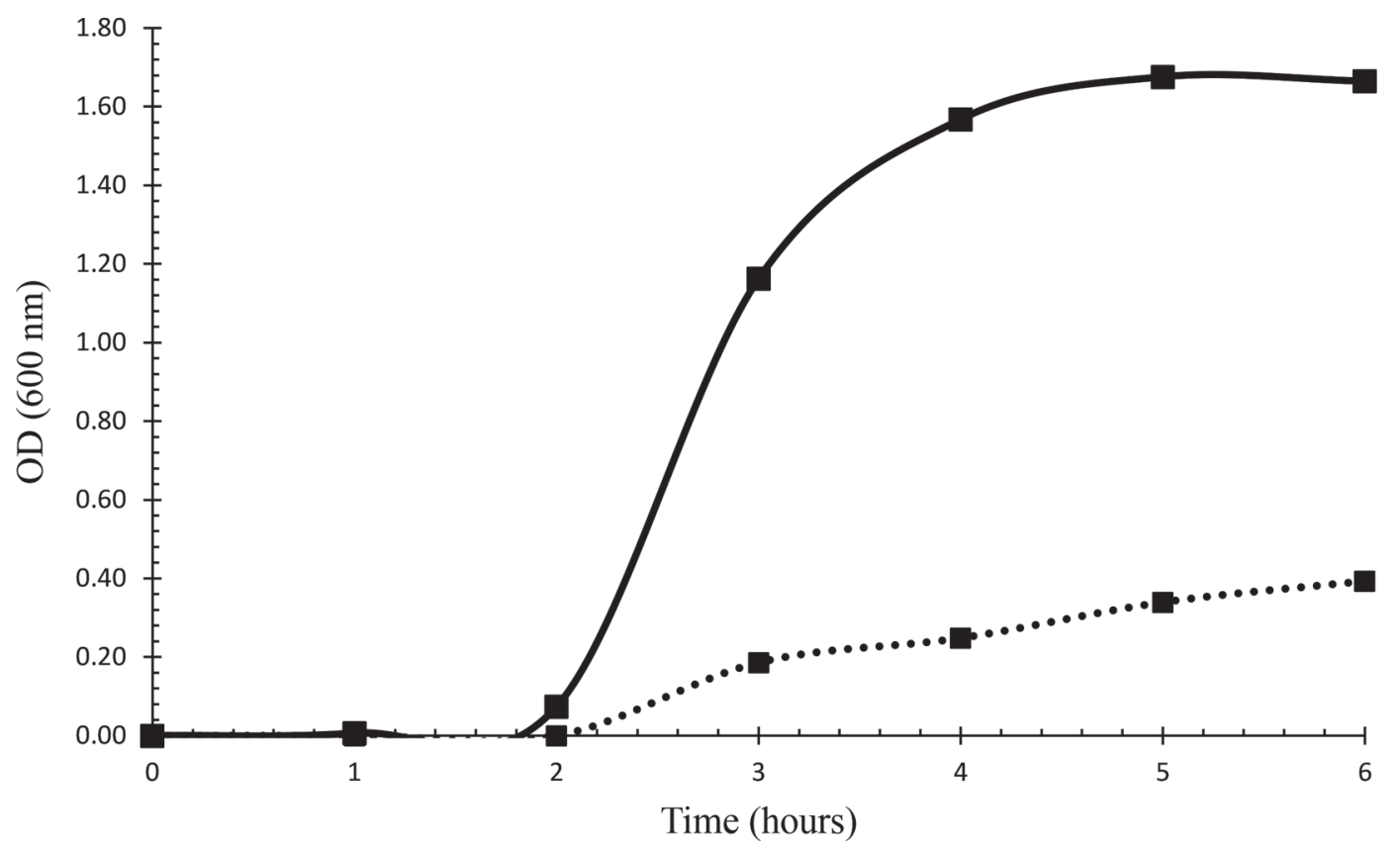

Figure 4. Growth of the bioindicator strain Listeria innocua 6a CLIST 2865 in the presence of bacteriocin ST16Pa (dotted line) and control without bacteriocin ST6Pa (continuous line). Error bars, corresponding to SD $(\mathrm{n}=2)$, are smaller than the size of markers. OD $=$ optical density. 
low yield (only $3 \%$ ), the purification fold did in fact increase up to 13.71. On the other hand, the same protocol failed in the purification of bacteriocin produced in supplemented whey powder formulation $(2 \%$ yield and purification fold decrease to 0.07 ), likely due to its $130 \%$ higher content of total proteins compared with the fermented MRS broth, thus requiring additional preliminary purification steps or even a different purification protocol. Garsa et al. (2014), using supplemented cheese whey to produce pediocin PA-1, proposed its purification by an aqueous two-phase system (ATPS) followed by ultrafiltration step. After the ATPS extraction, the authors achieved a $320 \%$ increase in pediocin PA-1 yield, which was further increased to $384 \%$ at the end of the ultrafiltration step; the purification fold was 4 and 7.3, respectively. These results might have been due to removal of protein contaminants responsible for suppression of pediocin PA-1 antimicrobial activity or its inactivation. Likewise, Sabo et al. (2018), using ATPS for bacteriocin partitioning from clarified broth of Lb. plantarum ST16Pa, demonstrated the potential of this system as an initial step for bacteriocin recovery and purification. Considering that this strain is the same used in the present work, using ATPS as a prepurification step may be a promising alternative to achieve the bacteriocin purification from supplemented whey powder.

\section{CONCLUSIONS}

Although the PB experimental design used in this work may have not been the best statistical tool to optimize bacteriocin ST16Pa production by Lb. plantarum ST16Pa in shake flasks because it is not able to point out the possible combined effects of multiple variables, it allowed the identification of a supplemented whey powder formulation whose fermentation ensured an increased antimicrobial activity compared with a previous attempt in cheese whey. A culture performed in bioreactor using the best whey powder formulation under the same conditions as those used in shake flasks showed almost the same fermentation parameters and bacteriocin antimicrobial activity against $L$. innocua 6a CLIST 2865. The attempt to purify bacteriocin ST16Pa by preliminary precipitation with ammonium sulfate and subsequent SPE was effective on the cellfree supernatant from the fermented MRS broth taken as a control but failed with the CFS from fermented whey powder formulation, likely because of a much higher level of contaminating proteins. Therefore, the next effort in this direction will be the addition to the purification protocol of a step of liquid-liquid extraction by ATPS that already proved to be very efficient as a tool to prepurify other proteins. 


\section{ACKNOWLEDGMENTS}

The authors are grateful to Svetoslav D. Todorov for providing bacteriocinogenic Lactobacillus plantarum ST16Pa for the present study. This work was supported by São Paulo Research Foundation (FAPESP process \# 2018/14822-6).

\section{REFERENCES}

Aasen, I. M., T. Møretrø, T. Katla, L. Axelsson, and I. Storrø. 2000. Influence of complex nutrients, temperature and $\mathrm{pH}$ on bacteriocin production by Lactobacillus sakei CCUG 42687. Appl. Microbiol. Biotechnol. 53:159-166.

Archer, D. L. 2018. The evolution of FDA's policy on Listeria monocytogenes in ready-to-eat foods in the United States. Curr. Opin. Food Sci. 20:64-68.

Azhar, N. S., N. H. M. Zin, and T. H. T. A. Hamid. 2017. Lactococcus lactis strain A5 producing nisin-like bacteriocin active against Gram-positive and negative bacteria. Trop. Life Sci. Res. 28:107118.

Balciunas, E. M., F. A. C. Martinez, S. D. Todorov, B. D. G. M. Franco, A. Converti, and R. P. S. Oliveira. 2013. Novel biotechnological applications of bacteriocins: A review. Food Control 32:134-142.

Bali, V., P. S. Panesar, and M. B. Bera. 2016. Trends in utilization of agro-industrial byproducts for production of bacteriocins and their biopreservative applications. Crit. Rev. Biotechnol. 36:204-214.

Blom, H., T. Katla, B. F. Hagen, and L. Axelsson. 1997. A model assay to demonstrate how intrinsic factors affect diffusion of bacteriocins. Int. J. Food Microbiol. 38:103-109.

Bogovič-Matijašić, B., and I. Rogelj. 1998. Bacteriocin complex of Lactobacillus acidophilus LF221-Production studies in MRS media at different $\mathrm{pH}$ values and effect against Lactobacillus helveticus ATCC 15009. Process Biochem. 33:345-352.

Brandelli, A., D. J. Daroit, and A. P. F. Corrêa. 2015. Whey as a source of peptides with remarkable biological activities. Food Res. Int. 73:149-161.

Briczinski, E. P., and R. F. Roberts. 2002. Production of an exopolysaccharide-containing whey protein concentrate by fermentation of whey. J. Dairy Sci. 85:3189-3197.

Brinques, G. B., M. C. Peralba, and M. A. Z. Ayub. 2010. Optimization of probiotic and lactic acid production by Lactobacillus plantarum in submerged bioreactor systems. J. Ind. Microbiol. Biotechnol. 37:205-212.

Cabo, M. L., M. A. Murado, M. P. Gonzalez, J. A. Vazquez, and L. Pastoriza. 2001. An empirical model for describing the effects of nitrogen sources on nisin production. Lett. Appl. Microbiol. $33: 425-429$.

Cardoso, J. A., A. Avelino, S. Junior, M. L. T. Nunes, M. A. Z Figueiredo, K. Cherubini, and F. G. Salum. 2017. Salivary alphaamylase enzyme, psychological disorders, and life quality in patients with recurrent aphthous stomatitis. Int. J. Dent. 2017:5269856.

Cintas, L. M., C. Herranz, P. E. Hernández, M. P. Casaus, and I. F. Nes. 2001. Review: Bacteriocins of lactic acid bacteria. Food Sci. Technol. Int. 7:281-305.

Cotter, P. D., C. Hill, and R. P. Ross. 2005. Bacteriocins: Developing innate immunity for food. Nat. Rev. Microbiol. 3:777-788.

De Vuyst, L., R. Callewaert, and K. Crabbe. 1996. Primary metabolite kinetics of bacteriocin biosynthesis by Lactobacillus amylovorus and evidence for stimulation of bacteriocin production under unfavourable growth conditions. Microbiology 142:817-827.

De Vuyst, L., and E. J. Vandamme. 1994. Microbiology, genetics and applications. Page 91-142 in Bacteriocins of Lactic Acid Bacteria. L. De Vuyst and E. J. Vandamme, ed. Blackie Academic and Professional, London, UK.

Garsa, A. K., R. Kumariya, A. Kumar, P. Lather, S. Kapila, and S. K. Sood. 2014. Industrial cheese whey utilization for enhanced production of purified pediocin PA-1. Lebensm. Wiss. Technol. $59: 656-665$.
González-Siso, M. I. 1996. The biotechnological utilization of cheese whey: A review. Bioresour. Technol. 57:1-11.

Guerra, N. P., and L. Pastrana. 2001. Enhanced nisin and pediocin production on whey supplemented with different nitrogen sources. Biotechnol. Lett. 23:609-612.

Holzapfel, W. H. 2002. Appropriate starter culture technologies for small-scale fermentation in developing countries. Int. J. Food Microbiol. 75:197-212.

Kennedy, M., and D. Krouse. 1999. Strategies for improving fermentation medium performance: A review. J. Ind. Microbiol. Biotechnol. $23: 456-475$.

Keppler, K., R. Geisen, and W. H. Holzapfel. 1994. An $\alpha$-amylase sensitive bacteriocin of Leuconostoc carnosum. Food Microbiol. 11:39-45.

Kim, W. S., R. J. Hall, and N. W. Dunn. 1997. The effect of nisin concentration and nutrient depletion on nisin production of Lactococcus lactis. Appl. Microbiol. Biotechnol. 48:449-453.

Koutinas, A. A., H. Papapostolou, D. Dimitrellou, N. Kopsahelis, E. Katechaki, A. Bekatorou, and L. A. Bosnea. 2009. Whey valorisation: A complete and novel technology development for dairy industry starter culture production. Bioresour. Technol. 100:37343739.

Lee, N.-K., and H.-D. Paik. 2001. Partial characterization of lacticin NK24, a newly identified bacteriocin of Lactococcus lactis NK24 isolated from Jeot-gal. Food Microbiol. 18:17-24.

Montgomery, D. C., C. M. Borror, and J. D. Stanley. 1997. Some cautions in the use of Plackett-Burman designs. Qual. Eng. 10:371381.

Myer, R. H., and D. C. Montgomery. 2002. Response Surface Methodology: Process and Product Optimization Using Designed Experiment. Wiley, New York, NY.

Panesar, P., J. Kennedy, D. Gandhi, and K. Bunko. 2007. Bioutilisation of whey for lactic acid production. Food Chem. 105:1-14.

Panesar, P. S., J. F. Kennedy, C. J. Knill, and M. Kosseva. 2010. Production of $\mathrm{L}(+)$ lactic acid using Lactobacillus casei from whey. Braz. Arch. Biol. Technol. 53:219-226.

Pleissner, D., and J. Venus. 2016. Utilization of protein-rich residues in biotechnological processes. Appl. Microbiol. Biotechnol. 100:21332140.

Prazeres, A. R., F. Carvalho, and J. Rivas. 2012. Cheese whey management: A review. J. Environ. Manage. 110:48-68.

Sabo, S. S., A. Converti, S. D. Todorov, J. M. Domínguez, and R. P. S. Oliveira. 2015. Effect of inulin on growth and bacteriocin production by Lactobacillus plantarum in stationary and shaken cultures. Int. J. Food Sci. Technol. 50:864-870.

Sabo, S. S., A. M. Lopes, V. C. Santos-Ebinuma, C. O. Rangel-Yagui, and R. P. S. Oliveira. 2018. Bacteriocin partitioning from a clarified fermentation broth of Lactobacillus plantarum ST16Pa in aqueous two-phase systems with sodium sulfate and choline-based salts as additives. Process Biochem. 66:212-221.

Sabo, S. S., N. Pérez-Rodríguez, J. M. Domínguez, and R. P. S. Oliveira. 2017. Inhibitory substances production by Lactobacillus plantarum ST16Pa cultured in hydrolyzed cheese whey supplemented with soybean flour and their antimicrobial efficiency as biopreservatives on fresh chicken meat. Food Res. Int. 99:762-769.

Sabo, S. S., M. Vitolo, J. M. D. González, and R. P. S. Oliveira. 2014 Overview of Lactobacillus plantarum as a promising bacteriocin producer among lactic acid bacteria. Food Res. Int. 64:527-536.

Seo, S. H., M. Jung, and W. J. Kim. 2014. Antilisterial and amylasesensitive bacteriocin producing Enterococcus faecium SH01 from Mukeunji, a Korean over-ripened kimchi. Food Sci. Biotechnol. 23:1177-1184.

Siezen, R. J., V. A. Tzeneva, A. Castioni, M. Wels, H. T. Phan, J. L. Rademaker, M. J. Starrenburg, M. Kleerebezem, D. Molenaar, and J. E. van Hylckama Vlieg. 2010. Phenotypic and genomic diversity of Lactobacillus plantarum strain isolated from various environmental niches. Environ. Microbiol. 12:758-773.

Smithers, G. W. 2015. Whey-ing up the options-Yesterday, today and tomorrow. Int. Dairy J. 48:2-14.

Swaminathan, B., and P. Gerner-Smidt. 2007. The epidemiology of human listeriosis. Microbes Infect. 9:1236-1243. 
Todorov, S. D., and L. M. T. Dicks. 2005. Characterization of bacteriocins produced by lactic acid bacteria isolated from spoiled black olives. J. Basic Microbiol. 45:312-322.

Todorov, S. D., H. Prévost, M. Lebois, X. Dousset, J. G. LeBlanc, and B. D. G. M. Franco. 2011. Bacteriocinogenic Lactobacillus plantarum ST16Pa isolated from papaya (Carica papaya)-From isolation to application: Characterization of a bacteriocin. Food Res. Int. 44:1351-1363.

Todorov, S., M. Wachsman, T. Ignatova-Ivanova, and I. Ivanova. 2014. Lactobacillus plantarum ST16Pa-Are we ready to use it as biopreservative culture? Bulg. J. Agric. Sci. 20:55-58.

Ummadi, M. S., and M. Curic-Bawden. 2010. Use of protein hydrolysates in industrial starter culture fermentations. Pages 91-114 in Protein Hydrolysates in Biotechnology. V. K. Pasupuleti and A. L. Demain, ed. Springer, Dordrecht, the Netherlands.

Ünlü, G., B. Nielsen, and C. Ionita. 2015. Production of antilisterial bacteriocins from lactic acid bacteria in dairy-based media: A comparative study. Probiotics Antimicrob. Proteins 7:259-274.

van Reenen, C. A., L. M. T. Dicks, and M. L. Chikindas. 1998. Isolation, purification and partial characterization of plantaricin 423, a bacteriocin produced by Lactobacillus plantarum. J. Appl. Microbiol. 84:1131-1137.
Vignolo, G. M., M. N. D. Kairuz, A. A. P. R. Holgado, and G. Oliver. 1995. Influence of growth conditions on the production of lactocin 705, a bacteriocin produced by Lactobacillus casei CRL 705. J. Appl. Bacteriol. 78:5-10.

Voysey, P., and R. Betts. 2017. In defense of the European $100 \mathrm{cfu}$ of Listeria monocytogenes/g in ready-to-eat foods. Pages 375-392 in Foodborne Pathogens. J. Gurtler, M. Doyle, J. and Kornacki, ed. Springer, Dordrecht, the Netherlands.

Wen, L. S., K. Philip, and N. Ajam. 2016. Purification, characterization and mode of action of plantaricin K25 produced by Lactobacillus plantarum. Food Control 60:430-439.

Xie, Y., H. An, Y. Hao, Q. Qin, Y. Huang, Y. Luo, and L. Zhang. 2011. Characterization of an anti-Listeria bacteriocin produced by Lactobacillus plantarum LB-B1 isolated from koumiss, a traditionally fermented dairy product from China. Food Control 22:1027-1031.

Yadav, J. S. S., S. Yan, S. Pilli, L. Kumar, R. D. Tyagi, and R. Y. Surampalli. 2015. Cheese whey: A potential resource to transform into bioprotein, functional/nutritional proteins and bioactive peptides. Biotechnol. Adv. 33:756-774.

Zamfir, M., I.-R. Stefan, and S.-S. Grosu-Tudor. 2016. Influence of growth medium composition on the bacteriocin activity of some lactic acid bacteria. Rom. Biotechnol. Lett. 22:12126-12135. 